\title{
P300 as an auxiliary method in clinical practice: A review of literature
}

\author{
Marina Titlic ${ }^{1,2}$, Mario Mihalj ${ }^{1}$, Amira Beganović Petrović3 ${ }^{3}$ Enra Suljic ${ }^{3}$ \\ 'Department of Neurology, Split University Hospital, Split, Croatia, ${ }^{2}$ School of Medicine, University of Split, Split, Croatia, \\ ${ }^{3}$ Department of Neurology, Sarajevo University Hospital, Sarajevo, Bosnia and Herzegovina
}

\begin{abstract}
Cognitive functions can be assessed and followed up over a period of time with cognitive evoked potentials (CEP) P300. In this context, brainstem auditory evoked potentials (BAEP) are most commonly used, but visual evoked potentials (VEP) are utilized as well. The research in this area has demonstrated that these techniques could be used as a supplemental method in diagnostics of numerous diseases such as Alzheimer's disease, mild cognitive impairment, vascular dementia, epilepsy, craniocerebral trauma, Parkinson's disease, multiple sclerosis, and other degenerative diseases. In addition, P300 can also be used as an auxiliary method in the diagnostics of mental disorders conditions such as schizophrenia, panic disorders, narcotic drug addiction, nicotinism, alcoholism, etc. The method assists in monitoring the course of diseases leading to encephalopathy, such as liver and kidney damage and grave anaemia. The advantages of P300 testing are easy application, non-invasiveness, and an unlimited number of potential applications. Moreover, the results obtained with this method are measurable and can be compared.
\end{abstract}

Keywords: P300; cognitive; clinical practice

\section{INTRODUCTION}

Neuropsychological tests are applied in assessing cognitive, cortical functions in patients with neurological and mental diseases, brain trauma, and damage resulting from other diseases (1-3). Event-related potential (ERP) is a non-invasive electrophysiological method. It can be used to assess different aspects of human cognitive information processing. ERP components such as auditory evoked P300,

\footnotetext{
*Corresponding author: Marina Titlic,

Department of Neurolgy, University of Split, Spinciceva 1,

Split 21000, Croatia. E-mail: marina.titlic@gmail.com

Submitted: 15 July 2016/Accepted: 19 November 2016
}

DOI: http://dx.doi.org/10.17532/jhsci.2016.304

UNIVERSITY OF SARAJEVO FACULTY OF HEALTH STUDIES associated with cognitive processes (i.e., attention and orientation), show low amplitude and long latency in acute and chronic diseases (4-6). P300 testing is an unbiased and non-invasive method, standardized for assessing cognitive processes (7-10). We have reviewed the existing literature in this field to better understand the role of P300 testing in diagnostics of different diseases.

\section{Review of literature}

We performed a systematic literature search and review of publications identified in the MEDLINE database (searched through September 2009). The search term was "P300, cognitive", and the search was limited to clinical trials and articles in English. 
The search was extended by the review of bibliographies from pertinent original reports and review articles. The research included 1212 references on P300.

P300 testing has been demonstrated to be a method of choice in differential diagnostic assessment of neurological and psychiatric diseases (Table 1). Clinical research showed significant changes in P300 parameters, such as lowered amplitude and extended latency, in patients with dementia, Alzheimer's disease, and mild cognitive impairment [MCI] (11-19). A smaller number of studies indicated changes in P300 in patients with epilepsy, and in those taking antiepileptic drugs $(10,20)$. A few studies indicated specific changes in amplitude and latency of P300 in clinically isolated syndrome and multiple sclerosis, as well as effects of interferon beta- $1 \mathrm{~b}$ to cognitive functions, even the P300 characteristics (21-23). Some studies indicated changes in P300 characteristics in patients with Parkinson's disease (the changes correlated with the degree of the disease determined according to the Hoehn and Yahr scale), growth hormone deficiency, Huntington's disease, Tourette syndrome, and narcolepsy $(2,9,24-27)$. Changes of P300 characteristics, lowered amplitude, and extended latency have also been noticed in schizophrenia (28-36), post-traumatic stress disorder $(36,37,40)$, endogenous psychoses (38-41), panic disorder (42-45), and depressive patients $(46,47)$. Additionally, a few papers described changes of P300 in impulsive aggressive criminals and obsessive-compulsive disor$\operatorname{der}(48,49)$.

Cognitive damage often results from craniocerebral trauma. The damage and gravity dysfunction are assessed by neuropsychological and neurophysiological analysis, where cognitive evoked potentials (CEP) P300 is among the preferred methods (50-53).

Some studies reported changes in P300 amplitude and latency in cases of chronic consumption of nicotine, alcohol, as well as cannabis, opioids, cocaine, and ecstasy (Table 2) (8,54-60).

Isolated research has been performed on CEP P300 in patients with epilepsy taking different antiepileptic drugs, such as: topiramate, valproate, and lamotrigine (61-63). These studies were based on measuring and comparing CEP P300 parameters while the patients were taking the drugs.

Cognitive damage in some systemic diseases can be assessed with CEP P300 (64-78). Improvements in

TABLE 1. Neurological and psychiatric diseases with confirmed changes of P300 wave parameters

\begin{tabular}{|c|c|}
\hline Disease & Studies \\
\hline Dementia & Uemura et al. (11), Egerházi et al. (17), Egerházi et al. (18) \\
\hline Alzheimer's disease & $\begin{array}{l}\text { Bennys et al. (12), Juckel et al. (14), Yener et al. (15), van Deursen et al. (16), Egerházi } \\
\text { et al. (17), Egerházi et al. (18) }\end{array}$ \\
\hline Mild cognitive impairment & $\begin{array}{l}\text { Bennys et al. (12), Golob et al. (13), van Deursen et al. (16), Egerházi et al. (17), Egerházi } \\
\text { et al. (18), Pappaliagkas et al. (19) }\end{array}$ \\
\hline Epilepsy & Zgorzalewicz (10), Ozmenek et al. (20) \\
\hline Clinically isolated syndrome & Kocer et al. (21) \\
\hline Multiple sclerosis & Magnié et al. (22), Flechter et al. (23) \\
\hline Parkinson's disease & Hayashi et al. (24) \\
\hline Growth hormone deficiency & Tanriverdi et al. (25), Braverman et al. (26) \\
\hline Huntington's disease & Beste et al. (9) \\
\hline Narcolepsy & Saletu et al. (2) \\
\hline Tourette syndrome & Thibault et al. (27) \\
\hline Schizophrenia & $\begin{array}{l}\text { Ford et al. (28), van der Stelt and Belger (29), Takahashi et al. (30), Zhang et al. (31), Higuchi } \\
\text { et al. (32), Wood et al. (33), Ozgürdal et al. (1), Sumiyoshi et al. (34), Turetsky et al. (35), Galletly } \\
\text { et al. (36), Veltmeyer et al. (37) }\end{array}$ \\
\hline Endogenous psychoses & Lebedeva et al. (38), Lebedeva et al. (39), Bramon et al. (40) \\
\hline Post-traumatic stress disorder & Veltmeyer et al. (37), Shucard et al. (41) \\
\hline Panic disorder & Tuter (42), Gordeev (43), Gordeev (44), Gordeev (45) \\
\hline Depression & Coullaut-Valera García et al. (46), Zhang et al. (47) \\
\hline Impulsive aggressive behavior & Zukov et al. (48) \\
\hline Obsessive-compulsive disorder & Gohle et al. (49) \\
\hline
\end{tabular}


the treatment and recovery can be followed in the same way. So far, changes in P300 characteristics, amplitude, and latency have been monitored in the following systemic diseases: anaemia, hepatic insufficiency, diabetes mellitus type 1, hypothyroidism, chronic obstructive pulmonary disease (COPD), organophosphorus insecticide poisoning, and HIV-1 neurologically asymptomatic seropositive individuals (Table 3).

\section{DISCUSSION}

Cognitive abilities include a number of qualitative characteristics that can be assessed with different neuropsychological tests. Recently, neurophysiological tests with CEP P300 are gaining attention (79-81). During the testing procedure, both auditory and visual stimuli are used. These are referred to as brainstem auditory evoked potentials (BAEP) and visual evoked potentials (VEP), and BAEP are used more frequently. In addition, comparative analysis of neuropsychological and neurophysiological P300 tests showed a statistically significant correlation, with high specificity and sensitivity (79-83). Changes of CEP P300 are characterized by extended latency and low wave amplitude. Numerous studies showed alterations of CEP P300 in neurological and psychiatric diseases, as well as consequences of traumatic

TABLE 2. Substances that cause addiction and results in altered P300

\begin{tabular}{ll}
\hline Addictive substances & Studies \\
\hline Nicotine & Müller et al. (8), Guney et al. (54) \\
Alcohol & Naziel et al. (55), Maurage et al. (56) \\
Cannabis & Roser et al. (57) \\
Opioid & Singh et al. (58) \\
Cocaine & Gooding et al. (59) \\
Ecstasy & de Sola et al. (60) \\
\hline
\end{tabular}

damages of the brain, that is, craniocerebral injuries (11-53). Different substances that cause addiction, from alcohol and nicotine to various opiates, lead to changes in cognitive functions, including changes in P300 parameters, due to brain damage (54-60). Moreover, with P300 testing, damage of cognitive functions resulting from taking different medicines, especially antiepileptic drugs, can also be monitored (61-63). Additionally, P300 characteristics help diagnosing cognitive damage resulting from systemic diseases, such as anaemia, uremia (renal insufficiency), hepatic encephalopathy, systemic lupus erythematosus, diabetes mellitus, hypothyreosis, as well as COPD (64-76). Moreover, cognitive function damage in patients with HIV-1 neurologically asymptomatic seropositive can be assessed with P300 testing (78). Finally, changes of P300 parameters are observed in organophosphorus insecticide poisoning (77).

CEP P300 tests are easy to apply, can be repeated often, there are no unwanted side effects or radiation, and the application is very simple. Also, the test is unbiased and a tested individual cannot influence the results. The test results (wave amplitude and latency) are expressed numerically. Therefore, the results can be easily compared at various stages of a disease, and the brain damage as well as the healing process can be monitored. All the mentioned above indicate that CEP P300 is a method of choice in differential diagnostics of cognitive functions. This is a preferred supplemental method in diagnostics of cognitive damage in clinical practice.

\section{CONCLUSION}

CEP P300 testing is a simple, quantitative, diagnostic method used in diagnosing cognitive damage in

TABLE 3. Systemic diseases that cause damage to cognitive functions measurable with P300

\begin{tabular}{ll}
\hline Disease & Studies \\
\hline Anaemia & Otero et al. (64), Khedr et al. (65), Kececi et al. (66) \\
Hepatic encephalopathy & Reeves et al. (67), Teodoro et al. (68), Guerit et al. (69) \\
Neuropsychiatric systemic lupus erythematosus & Mostafa et al. (70), Buca et al. (71) \\
Uremia & Madan et al. (72) \\
Diabetes mellitus type 1 & Cooray et al. (73) \\
Hypothyroidism & Nazliel et al. (74), Anjana et al. (75) \\
Chronic obstructive pulmonary disease & Kirkil et al. (76) \\
Organophosphorus insecticide poisoning & Dassanayake et al. (77) \\
HIV-1 seropositive subjects & Amador Romero et al. (78) \\
\hline
\end{tabular}


clinical practice. The main advantage of this method compared to other diagnostic methods is the ability to compare the measurement results easily and to monitor the progress of disease.

\section{CONFLICT OF INTEREST}

The authors declare no conflict of interest.

\section{REFERENCES}

1. Ozgürdal S, Gudlowski Y, Witthaus H, Kawohl W, Uhl I, Hauser M, et al. Reduction of auditory event related P300 amplitude in subjects with at-risk mental state for schizophrenia. Schizophr Res 2008;105(3):272-8.

https://doi.org/10.1016/j.schres.2008.05.017.

2. Saletu M, Anderet P, Saletu-Zyhlarz GM, Mandl M, Zeithofer J, Saletu B. Event-related-potential low-resolution brain electromagnetic tomography (ERP-LORETA) suggests decreased energetic resources for cognitive processing in narcolepsy. Clin Neurophysiol 2008;119(8):1782-94.

https://doi.org/10.1016/j.clinph.2008.04.297.

3. Gómez CM, Flores A, Digiacomo MR, Ledesma A, González-Rosa J. P3a and $\mathrm{P} 3 \mathrm{~b}$ components associated to the neurocognitive evaluation of invalidly cued targets. Neurosci Lett 2008;430(2):181-5.

https://doi.org/10.1016/j.neulet.2007.10.049.

4. Xu G, Zhang Y, Hozu H, Yan W. Event-related potential studies of attention to shape under different stimuli tasks. Conf Proc IEEE Eng Med Biol Soc 2006;:Suppl:6618-21.

5. Polich J. Updating P300: An integrative theory of P3a and P3b. Clin Neurophysiol 2007;118(10):2128-48.

https://doi.org/10.1016/j.clinph.2007.04.019.

6. Vanhaudenhuyse A, Laureys S, Perrin F. Cognitive event-related potentials in comatose and post-comatose states. Neurocrit Care 2008;8(2):262-70. https://doi.org/10.1007/s12028-007-9016-0.

7. Rektor I, Brázdil M, Nestrasil I, Bares M, Daniel P. Modifications of cognitive and motor tasks affect the occurrence of event-related potentials in the human cortex. Eur J Neurosci 2007;26(5):1371-80.

https://doi.org/10.1111/j.1460-9568.2007.05713.x.

8. Müller BW, Specka M, Steinchen N, Zerbin D, Lodemann E, Finkbeiner T, et al. Auditory target processing in methadone substituted opiate addicts: The effect of nicotine in controls. BMC Psychiatry 2007;7:63.

https://doi.org/10.1186/1471-244X-7-63.

9. Beste $C$, Saft $C$, Güntürkün $O$, Falkenstein $M$. Increased cognitive functioning in symptomatic Huntington's disease as revealed by behavioral and event-related potential indices of auditory sensory memory and attention. J Neurosci 2008;28(45):11695-702.

https://doi.org/10.1523/JNEUROSCI.2659-08.2008.

10. Zgorzalewicz M. Long latency auditory evoked potentials in schoolchildren and adolescents with epilepsy. Przegl Lek 2006;63(Suppl 1):8-13.

11. Uemura J, Hoshiyama M. Variability of P300 in elderly patients with dementia during a single day. Int J Rehabil Res 2007;30(2):167-70.

https://doi.org/10.1097/MRR.0b013e32813a2e6f.

12. Bennys K, Portet F, Touchon J, Rondouin G. Diagnostic value of event-related potentials N200 and P300 subcomponents in early diagnosis of Alzheimer's disease and mild cognitive impairment. J Clin Neurophysiol 2007;24(5):405-12.

https://doi.org/10.1097/WNP.0b013e31815068d5.

13. Golob EJ, Irimajiri R, Starr A. Auditory cortical activity in amnestic mild cognitive impairment: Relationship to subtype and conversion to dementia. Brain 2007;130(Pt 3):740-52.

https://doi.org/10.1093/brain/awl375.

14. Juckel G, Clotz F, Frodl T, Kawohi W, Hampel H, Pogarell O, et al. Diagnostic usefulness of cognitive auditory event-related P300 subcomponents in patients with Alzheimers Disease? J Clin Neurophysiol 2008;25(3):147-52.

https://doi.org/10.1097/WNP.0b013e3181727c95.

15. Yener G, Güntekin B, Baser E. Event-related delta oscillatory responses of Alzheimer patients. Eur J Neurol 2008;15(6):540-7.

https://doi.org/10.1111/j.1468-1331.2008.02100.x.

16. van Deursen JA, Vuurman EF, Smits LL, Verhey FR, Riedel WJ. Response speed, contingent negative variation and P300 in Alzheimer's disease and MCl. Brain Cogn 2009;69(3):592-9.

https://doi.org/10.1016/j.bandc.2008.12.007.

17. Egerházi A, Glaub T, Balla P, Berecz R, Degrell I. P300 in mild cognitive impairment and in dementia. [Article in Hungarian]. Psychiatr Hung 2008;23(5):349-57.

18. Egerházi A. The early diagnosis and differential diagnosis of Alzheimer's disease with clinical methods. Orv Hetil 2008;149(51):2433-40.

https://doi.org/10.1556/OH.2008.28429.

19. Pappaliagkas V, Kimiskidis V, Tsolaki M, Anogianakis G. Usefulness of event-related potentials in the assessment of mild cognitive impairment. BMC Neurosci 2008;9:107.

https://doi.org/10.1186/1471-2202-9-107.

20. Ozmenek OA, Nazliel B, Leventoğlu A, Bilir E. The role of event related potentials in evaluation of subclinical cognitive dysfunction in epileptic patients. Acta Neurol Belg 2008;108(2):58-63.

21. Kocer B, Unal T, Nazliel B, Biyikli Z, Yesilbudak Z, Karakas S, et al. Evaluating sub-clinical cognitive dysfunction and event-related potentials (P300) in clinically isolated syndrome. Neurol Sci 2008;29(6):435-44. https://doi.org/10.1007/s10072-008-1020-4.

22. Magnié MN, Bensa C, Laloux L, Bertogliati C, Faure S, Lebrun C. Contribution of cognitive evoked potentials for detecting early cognitive disorders in multiple sclerosis. Rev Neurol (Paris) 2007;163(11):1065-74. https://doi.org/10.1016/S0035-3787(07)74179-6.

23. Flechter S, Vardi J, Finkelsein Y, Pollak L. Cognitive dysfunction evaluation in multiple sclerosis patients treated with interferon beta- $1 \mathrm{~b}$ : An open-label prospective 1 year study. Isr Med Assoc J 2007;9(6):457-9.

24. Hayashi R, Hanyu N, Tamaru F. Cognitive impairment in Parkinson's disease: A 6 year follow-up study. Parkinsonism Relat Disord 1998;4(2):81-5. https://doi.org/10.1016/S1353-8020(98)00018-2.

25. Tanriverdi F, Yapislar H, Karaca Z, Unluhizarci K, Suer C, Kelestimur F. Evaluation of cognitive performance by using P300 auditory event related potentials (ERPs) in patients with growth hormone $(\mathrm{GH})$ deficiency and acromegaly. Growth Horm IGF Res 2009;19(1):24-30.

https://doi.org/10.1016/j.ghir.2008.05.002.

26. Braverman ER, Chen TJ, Prihoda TJ, Sonngtag W, Meshkin B, Downs BW, et al. Plasma growth hormones, P300 event-related potential and test of variables of attention (TOVA) are important neuroendocrinological predictors of early cognitive decline in a clinical setting: Evidence support by structural equation modeling (SEM) parameter estimates. Age (Dordr) 2007;29(2-3):55-67. https://doi.org/10.1007/s11357-007-9030-3.

27. Thibault G, O'Connor KP, Stip E, Lavoie ME. Electrophysiological manifestations of stimulus evaluation, response inhibition and motor processing in Tourette syndrome patients. Psychiatry Res 2009;167(3):202-20. https://doi.org/10.1016/j.psychres.2008.03.02.

28. Ford JM, Krystal JH, Mathalon DH. Neural synchrony in schizophrenia: From networks to new treatments. Schizophr Bull 2007;33(4):848-52. 


\section{https://doi.org/10.1093/schbul/sbm062.}

29. van der Stelt O, Belger A. Application of electroencephalography to the study of cognitive and brain functions in schizophrenia. Schizophr Bull 2007;33(4):955-70.

https://doi.org/10.1093/schbul/sbm016.

30. Takahashi S, Tanabe E, Sakai T, Matsuura M, Matsushima E, Obayashi S, et al. Relationship between exploratory eye movement, P300, and reaction time in schizophrenia. Psychiatry Clin Neurosci 2008;62(4):396-403. https://doi.org/10.1111/j.1440-1819.2008.01817.x.

31. Zhang Y, Lehmann M, Shobeiry A, Höfer D, Johannes S, Emrich HM, et al. Effects of quetiapine on cognitive functions in schizophrenic patients: A preliminary single-trial ERP analysis. Pharmacopsychiatry 2009;42(4):129-34. https://doi.org/10.1055/s-0028-1112133.

32. Higuchi $Y$, Sumiyoshi T, Kawasaki $Y$, Matsui M, Arai H, Kurachi M. Electrophysiological basis for the ability of olanzapine to improve verbal memory and functional outcome in patients with schizophrenia: A LORETA analysis of P300. Schizophr Res 2008;101(1-3):320-30.

https://doi.org/10.1016/j.schres.2008.01.020.

33. Wood SM, Potts GF, Martin LE, Kothmann D, Hall JF, Ulanday JB. Disruption of auditory and visual attention in schizophrenia. Psychiatry Res 2007;156(2):105-16

https://doi.org/10.1016/j.pscychresns.2007.04.014.

34. Sumiyoshi T, Higuchi $Y$, Itoh T, Matsui M, Arai H, Suzuki M, et al. Effect of perspirone on P300 electrophysiological activity and social cognition in schizophrenia: A three-dimensional analysis with sloreta. Psychiatry Res 2009;172(3):180-3.

https://doi.org/10.1016/j.pscychresns.2008.07.005.

35. Turetsky BI, Bilker WB, Siegel SJ, Kohler CG, Gur RE. Profile of auditory information-processing deficits in schizophrenia. Psychiatry Res 2009;165(1-2):27-37.

https://doi.org/10.1016/j.psychres.2008.04.013.

36. Galletly CA, McFarlane AC, Clark R. Differentiating cortical patterns of cognitive dysfunction in schizophrenia and posttraumatic stress disorder. Psychiatry Res 2008;159(1-2):196-206. https://doi.org/10.1016/j.psychres.2007.04.001.

37. Veltmeyer MD, Clark CR, McFarlane AC, Moores KA, Bryant RA, Gordon E. Working memory function in post-traumatic stress disorder: An event-related potential study. Clin Neurphysiol 2009;120(6):1096-1106. https://doi.org/10.1016/j.clinph.2009.03.024.

38. Lebedeva IS, Kaleda VG, Barkhatova AN. Neurophysiological characteristics of cognition during first episode in young men with endogenous psychoses. [Article in Russian]. Zh Nevrol Psikhiatr Im S S Korsakova 2007;107(2):12-20.

39. Lebedeva IS, Kaleda VG, Barkhatova AN. Neurophysiological characteristics of cognitive functions in patients with first episodes of endogenous psychosis. Neurosci Behav Physiol 2008;38(3):259-67.

https://doi.org/10.1007/s11055-008-0038-7

40. Bramon E, Dempster E, Frangou S, Shaikh M, Walshe M, Filbey FM, et al. Neuregulin-1 and the P300 waveform-a preliminary association study using a psychosis endophenotype. Schizophr Res 2008;103(1-3):178-85. https://doi.org/10.1016/j.schres.2008.03.025.

41. Shucard JL, McCabe DC, Szymanski H. An event-related potential study of attention deficits in posttraumatic stress disorder during auditory and visual Go/NoGo continuous performance tasks. Biol Psychol 2008;79(2):223-33. https://doi.org/10.1016/j.biopsycho.2008.05.005.

42. Tuter NV. Cognitive evoked potentials in panic disorders. Zh Nevrol Psikhiatr Im S S Korsakova 2008;108(8):47-51.

43. Gordeev SA. P300 component changes of the auditory event-related potential in the patients with typical and atypical panic attacks. [Article in
Russian]. Zn Vyssh Nerv Deiat Im I P Pavlova 2007;57(2):161-8.

44. Gordeev SA. Cognitive functions and nonspecific brain systems in patients with panic disorders. [Article in Russian]. Zh Nevrol Psikhiatr Im S S Korsakova 2007;107(6):54-60.

45. Gordeev SA. Cognitive functions and the state of nonspecific brain systems in panic disorders. Neurosci Behav Psysiol 2008;38(7):707-14.

https://doi.org/10.1007/s11055-008-9036-z.

46. Coullaut-Valera García J, Arbaiza Díaz del Rio I, Coullaut-Valera García R, Ortiz T. Alterations of P300 wave in occipital lobe in depressive patients. Actas Esp Psiquiatr 2007;35(4):243-8.

47. Zhang Y, Hauser U, Conty C, Emrich HM, Dietrich DE. Familial risk for depression and $\mathrm{p} 3 \mathrm{~b}$ component as a possible neurocognitive vulnerability marker. Neuropsychobiology 2007;55(1):14-20.

https://doi.org/10.1159/000103571.

48. Zukov I, Hrubý T, Kozelek P, Ptácek R, Paclt I, Harsa P. P300 wave: A comparative study of impulsive aggressive criminals. Neuro Endocrinol Lett 2008;29(3):379-84.

49. Gohle D, Juckel G, Mavrogiorgou P, Pogarell O, Mulert C, Rujescu D, et al. Electrophysiological evidence for cortical abnormalities in obsessive-compulsive disorder - A replication study using auditory event-related P300 subcomponents. J Psychiatr Res 2008;42(4):297-303. https://doi.org/10.1016/j.jpsychires.2007.01.003.

50. Lew HL, Gray M, Poole JH. Temporal stability of auditory event-related potentials in healthy individuals and patients with traumatic brain injury. J Clin Neurophysiol 2007;24(5):392-7.

https://doi.org/10.1097/WNP.0b013e31814a56e3

51. Elting JW, Maurits N, Weerden T, Spikman J, De Keyser J, can der Naalt J. P300 analysis techniques in cognitive impairment after brain injury: Comparison with neuropsychological and imaging data. Braub Inj 2008;22(11):870-81

https://doi.org/10.1080/02699050802403581.

52. Cui Y, Liu F, Zhang XY, Tang P, Liu P, Zhang B, et al. Auditory P300 in the patients with traumatic brain injury. [Article in Chinese]. Fa YI Xue Za Zhi 2009;25(1):19-23.

53. Lew HL, Gray M, Poole JH. Simultaneous measurement of perceptual and motor cortical potentials: Implications for assessing information processing in traumatic brain injury. Am J Phys Med Rehabil 2009;88(1):1-6.

https://doi.org/10.1097/PHM.0b013e3181911102.

54. Guney F, Genc BO, Kutlu R, Ihan BC. Auditory P300 event-related potential in tobacco smokers. J Clin Neurosci 2009;16(10):1311-5. https://doi.org/10.1016/j.jocn.2008.11.025.

55. Naziel B, Yavas G, Arikan Z, Ozon O, Aksoy OO, Irkec C. Event related potentials in children of alchoholics. Electromyogr Clin Neurophysiol 2008;47(6):315-8

56. Maurage $P$, Philippot $P$, Joassin F, Pauwels $L$, Pham T, Prieto EA, et al. The auditory-visual integration of anger is impaired in alcoholism: An event-related potentials study. J Psychiatry Neurosci 2008;33(2):111-22. https://doi.org/10.1016/j.jpsycho.2008.05.059.

57. Roser P, Juckel G, Rentzsch J, Nadulski T, Gallinat J, Stadelmann AM Effects of acute oral Delta9-tetrahydrocannabinol and standardized cannabis extract on the auditory P300 event-related potential in healthy volunteers. Eur Neuropsychopharmacol 2008;18(8):569-77. https://doi.org/10.1016/j.euroneuro.2008.04.008.

58. Singh SM, Basu D, Kohli A, Prabhakar S. Auditory P300 event-related potentials and neurocognitive functions in opioid dependent men and their brothers. Am J Addict 2009;18(3):198-205.

https://doi.org/10.1080/10550490902786975.

59. Gooding DC, Burroughs S, Boutros NN. Attentional deficits in cocaine-dependent patients: Converging behavioral and electrophysiological 
evidence. Psychiatry Res 2008;160(2):145-54.

https://doi.org/10.1016/j.psychres.2007.11.019.

60. de Sola S, Tarancón T, Pena-Casanova J, Espadaler JM, Langohr K, Poudevida S, et al. Auditory event-related potentials (P3) and cognitive performance in recreational ecstasy polydrug users: Evidence from a 12-month longitudinal study. Psychopharmacology (Berl) 2008;200(3):425-37.

https://doi.org/10.1007/s00213-008-1217-5.

61. Sun W, Wang W, Wu X, Wang Y. Antiepileptic drugs and the significance of event-related potentials. J Clin Neurophysiol 2007;24(3):271-6. https://doi.org/10.1097/WNP.0b013e31803bb334.

62. Sun W, Wang Y, Wang W, Wu Y. Attention changes in epilepsy patients following 3-month topiramate or valproate treatment revealed by event-related potential. Int J Psychophysiol 2008:68(3):235-41.

https://doi.org/10.1016/j.jpsycho.2008.02.003.

63. Titlic M, Isgum V, Nesek-Madaric V, Lusic I. The effects of lamictal (lamotrigin) on the cognitive functions in patients suffering from epilepsy. Eur $\mathrm{J}$ Neurology 2005;12(Suppl 2):92.

64. Otero GA, Pliego-Rivero FB, Porcayo-Mercado R, Medieta-Alcántara G. Working memory impairment and recovery in iron deficient children. Clin Neurophysiol 2008;119(8):1739-46.

https://doi.org/10.1016/j.clinph.2008.04.015.

65. Khedr E, Hjamed SA, Elbeih E, El-Shereef H, Ahmad Y, Ahmed S. Iron states and cognitive abilities in young adults: Neuropsychological and neurophysiological assesment. Eur Arch Psychiatry Clin Neurosci 2008;258(8):489-96.

https://doi.org/10.1007/s00406-008-0822-y.

66. Kececi H, Degirmenci Y. Quantitative EEG and cognitive evoked potentials in anemia. Neurophysiol Clin 2008;38(2):137-43.

https://doi.org/10.1016/j.neucli.2008.01.004.

67. Reeves RR, Struve FA, Rash CJ, Burke RS. P300 cognitive evoked potentials before and after liver transplantation. Metab Brain Dis 2007;22(2):139-44.

https://doi.org/10.1007/s11011-007-9055-4.

68. Teodoro V, Bragagnolo Jr M, Lucchesi L, Kondo M, Tufik S. Evaluation of the event-related potential (ERP-P300) in patients with hepatic cirrhosis without encephalopathy. Arq Gastroenterol 2008;45(1):82-6. https://doi.org/10.1590/S0004-28032008000100015.

69. Guerit JM, Amantini A, Fischer C, Kaplan PW, Mecarelli O, Schnitzler A, et al. Neurophysiological investigations of hepatic encephalopathy: ISHEN practice guidelines. Liver Int 2009;29(6):789-96.

https://doi.org/10.1111/j.1478-3231.2009.02030.x.

70. Mostafa GA, Nazif HK, El-Shahawi HH, Abd El-Aziz MM, Hassan MA. Antineuronal antibodies and electroneurophysiological studies in pediatric patients with neuropsychiatric systemic lupus erythematosus. Pediatr Allergy Immunol 2009;20(2):192-9.

https://doi.org/10.1111/j.1399-3038.2008.00753.x.

71. Buca A, Perkovic D, Martinovic-Kaliterna D, Vlastelica M, Titlic M.
Neuropsychiatric systemic lupus erythematosus: Diagnostic and clinical features according to revised ACR criteria. Coll Antropol 2009;33(1):281-8.

72. Madan P, Agarwal S, Kalra OP, Tandon OP. Effect of hemodialysis on cognitive function in ESRD patients. Ren Fail 2007;29(6):699-703.

https://doi.org/10.1080/08860220701460103.

73. Cooray GK, Maurex L, Brismar T. Cognitive impairment correlates to low auditory event-related potential amplitudes in type 1 diabetes. Psychoneuroendocrinology 2008;33(7):942-50.

https://doi.org/10.1016/j.psyneuen.2008.04.013.

74. Nazliel B, Yilmaz M, Kocer B, Yetkin I, Yesilbudak Z. Event related potentials in hypothyroidism. Electromyogr Clin Neurophysiol 2008;48(5):203-8.

75. Anjana Y, Tandon OP, Vaney N, Madhu SV. Cognitive status in hypothyroid female patients: Event-related evoked potential study. Neuroendocrinology 2008;88(1):59-66.

https://doi.org/10.1159/000117713.

76. Kirkil G, Tug T, Ozel E, Bulut S, Tekatas A, Muz MH. The evaluation of cognitive functions with $\mathrm{P} 300$ test for chronic obstructive pulmonary disease patients in attack and stable period. Clin Neurol Neurosurg 2007;109(7):553-60.

https://doi.org/10.1016/j.clineuro.2007.03.013.

77. Dassanayake T, Weerasinghe V, Dangahadeniya U, Kularatne $K$, Dawson A, Karalliedde L, et al. Long-term event-related potential changes following organophosphorus insecticide poisoning. Clin Neurophysiol 2008;119(1):144-50.

https://doi.org/10.1016/j.clinph.2007.09.134.

78. Amador Romero F, Pelegrina del Rio M, Mayor Ríos J. Cognitive slowing in cognitive-motor disorder associated to type 1 human immunodeficiency virus: TR and P300. Actas Esp Psiquiatr 2007;35(4):221-8.

79. Scott GG, O'Donnell PJ, Leuthold H, Serono SC. Early emotion word processing: Evidence from event-related potentials. Biol Psychol 2009;80(1):95-104.

https://doi.org/10.1016/j.biopsycho.2008.03.010.

80. Mantini D, Corbetta M, Perrucci MG, Romani GL, Del Gratta C. Large-scale brain networks account for sustained and transient activity during target detection. Neuroimage 2009;44(1):265-74.

https://doi.org/10.1016/j.neuroimage.2008.08.019.

81. Schiff S, Valenti P, Andrea P, Lot M, Bisiacchi P, Gatta A, et al. The effect of aging on auditory components of event-related brain potentials. Clin Neurophysiol 2008;119(8):1795-802.

https://doi.org/10.1016/j.clinph.2008.04.007.

82. Saillas E, El Yagoubi R, Semenza C. Sensory and cognitive processes of shifts of spatial attention induced by numbers: An ERP study. Cortex 2008;44(4):406-13.

https://doi.org/10.1016/j.cortex.2007.08.006.

83. Sawaki R, Katayama J. Distractor $\mathrm{P} 3$ is associated with attentional capture by stimulus deviance. Clin Neurophysiol 2008;119(6):1300-9.

https://doi.org/10.1016/j.clinph.2008.01.107. 